\title{
Erratum to: Retention and fate of groundwater-borne nitrogen in a coastal bay (Kinvara Bay, Western Ireland) during summer
}

\author{
C. Rocha $\cdot$ J. Wilson $\cdot$ J. Scholten $\cdot$ M. Schubert
}

Published online: 12 August 2015

(C) Springer International Publishing Switzerland 2015

\section{Erratum to: Biogeochemistry \\ DOI 10.1007/s10533-015-0116-1}

Corrected version:

Table 2 Summary of meteorological conditions obtained from the Met Éireann (www.met.ie) weather station at Oranmore, $14.4 \mathrm{~km}$ north of the town of Kinvarra, during the survey periods (2-4 days encompassing each of the full campaigns);

\begin{tabular}{lcccc}
\hline & July 2010 & June 2011 & September 2011 & July 2013 \\
\hline Air temperature $\left({ }^{\circ} \mathrm{C}\right)$ & 16.5 & 12.6 & 14.0 & 19.0 \\
Relative humidity (\%) & 0.835 & 0.764 & 0.895 & 0.847 \\
Wind speed $\left(\mathrm{km} \mathrm{h}^{-1}\right)$ & 5.25 & 5.25 & 6.75 & 3.33 \\
2-week cumulative precipitation $(\mathrm{mm})$ & 8.3 & 42.8 & 50.3 & 16.8 \\
Open-water evaporation $\left(\mathrm{mm} \mathrm{d}^{-1}\right)$ & 1.81 & 1.57 & 0.72 & 1.33 \\
\hline
\end{tabular}

cumulative precipitation determined by the sum of daily precipitation over the area going back two weeks (14 days) from and including the survey periods

The online version of the original article can be found under doi:10.1007/s10533-015-0116-1.

C. Rocha $(\bowtie) \cdot$ J. Wilson

Biogeochemistry Research Group, Geography

Department, School of Natural Sciences, Trinity College

Dublin, Dublin 2, Ireland

e-mail: rochac@tcd.ie

J. Scholten

Institute of Geosciences, University of Kiel, Kiel,

Germany

M. Schubert

UFZ - Helmholtz Centre for Environmental Research

Leipzig/Halle, Leipzig, Germany 